\title{
Biostimulator Enhancement of Kentucky Bluegrass Sod
}

\author{
J.M. Goatley, Jr. ${ }^{1}$, and R.E. Schmidt ${ }^{2}$ \\ Department of Crop and Soil Environmental Sciences, Virginia \\ Polytechnic Institute and State University, Blacksburg, VA 24061
}

Additional index words. Poa pratensis, triazoles, benzyladenine, seaweed extract, Fe

Abstract. This study was conducted to determine if foliar-applied biostimulators could enhance harvestability and transplanting of Kentucky bluegrass (Poa pratensis L.) sod. The systemic triazole fungicides propiconazole at $42 \mathrm{mg} \cdot \mathrm{m}^{-2}$ and triadimefon at $150 \mathrm{mg} \cdot \mathrm{m}^{-2}$ enhanced post-transplant rooting and sod strength of bluegrass. Propiconazole had the best sod enhancement effect, increasing sod tensile strength $23 \%$ and increasing transplant root lift strength $64 \%$ across three experiments. The synthetic cytokinin benzyladenine (BA) at $6 \mathrm{mg} \cdot \mathrm{m}^{-2}$ and seaweed $\mathrm{ex}$ tract (SWE, a freeze-dried extract of the seaweed Ascophyllum nodosum) at $0.3 \mathrm{ml}$ product $/ \mathrm{m}^{2}$ had little effect. The response to triadimefon was intermediate. Foliar applications of chelated $\mathrm{Fe}$ phosphate citrate at $112 \mathrm{mg} \cdot \mathrm{m}^{-2}$ did not enhance sod strength or rooting of Kentucky bluegrass when applied either alone or in combination with the biostimulator materials. Chemical names used: $1-(2-(2,4$-dichlorophenyl)-4-propyl-1,3-dioxo1an-2-ylmethyl)-lH-l,2,4-triazole(propiconazole);1-(4chlorophenoxy)-3,3-dimethyl-lH-(l,2,4-triazo1-l-yl)-butanone zylaminopurine (BA, benzyladenine).

Stimulation of Kentucky bluegrass shoot growth could provide early sod harvesting. Faster root initiation could improve establishment and reduce the potential for moisture stress of transplanted sod. Biostimulators (materials of little or no fertilizer value that accelerate plant growth, usually when used at low concentrations) may provide root and shoot stimulation.

BA, a highly active synthetic cytokinin, increases or maintains photosynthetic rates and delays leaf senescence (Chernyad'ev et al., 1986; Goatley and Schmidt, 1990a; Tao et al., 1983; White and Schmidt, 1988). BA-treated Kentucky bluegrass leaves have higher chlorophyll and nonstructural carbohydrate contents than untreated leaves (Kane and Smiley, 1983). Some systemic triazole fungicides promote photosynthetic rates, stimulate root and shoot initiation and development, and delay leaf senescence (Ballard et al., 1984; Gautam et al., 1984; Goatley and Schmidt, 1990a, 1990b; Kane and Smiley, 1983). Seaweed extracts (SWE), containing naturally occurring auxins, cytokinins, and gibberellic acids, increase root mass and the root : shoot ratio in several horticultural crops (Featonby Smith and Van Staden, 1983; Finnie and Van Staden, 1985; Nelson and Van Staden, 1984).

The objective of this study was to determine the influence of foliar applications of various biostimulator materials on sod strength

Received for publication 11 Dec. 1989. The cost of publishing this paper was defrayed in part by the payment of page charges. Under postal regulations, this paper therefore must be hereby marked advertisement solely to indicate this fact.

${ }^{1}$ Assistant Professor, Agronomy Dept., Mississippi State Univ., Mississippi State, MS 39762. ${ }^{2}$ Professor. and post-transplant rooting of Kentucky b l u e g r a s s.

Three experiments were performed in Summer 1987 on a mature 'Plush' Kentucky bluegrass sod established from seed in Sept. 1986 on a Lodi silt loam soil (typic Hapludult clayey, kaolinitic, mesic family, pH 6.4) at the Turfgrass Research Center, Blacksburg, Va. At the time of cutting, this area was a mature sod acceptable for harvest. Fertilizer was applied at seeding to provide $49 \mathrm{~kg} \cdot \mathrm{ha}^{-1}$ each of $\mathrm{N}, \mathrm{P}_{2} \mathrm{O}_{5}$, and $\mathrm{K}_{2} \mathrm{O}$. Additional $\mathrm{N}$ was applied at $49 \mathrm{~kg} \cdot \mathrm{ha}-{ }^{1}$ in Mar. 1987. The turf was maintained at a mowing height of $3.8 \mathrm{~cm}$ and irrigated as needed to promote turf establishment. Biostimulators used in these experiments were two systemic triazole fungicides (triadimefon at 150 $\mathrm{mg} \cdot \mathrm{m}^{-2}$ and propiconazole at $42 \mathrm{mg} \cdot \mathrm{m}^{-2}$ ), BA at $6 \mathrm{mg} \cdot \mathrm{m}^{-2}$, and a SWE (a freeze-dried extract of Ascophyllum nodosum containing $150 \mathrm{mg}$ glycol kinetin/liter; Agrimar Corp., Atlanta) at $0.3 \mathrm{ml}$ product $/ \mathrm{m}^{2}$. These materials were applied either alone or in combination with chelated $\mathrm{Fe}$ phosphate citrate (RGB Laboratories, Kansas City, Me.). In the subsequent analyses, there were no effects (neither main effects or interaction) involving $\mathrm{Fe}$, thus $\mathrm{Fe}$ treatments were pooled in the analyses of biostimulator effects. Foliar applications of these materials were made to $0.9 \times 1.8-\mathrm{m}$ plots by means of a compressed-air boom sprayer delivering aqueous solutions or suspensions of 748 liters $\cdot$ ha $^{-1}$ at $276 \mathrm{kPa}$.

Treatments in Expt. 1 were applied on 7 July and for Expts. 2 and 3 on 24 Aug. Sod strips $(30 \mathrm{~cm}$ wide and $2.2 \mathrm{~cm}$ deep) for post-transplant rooting measurements were harvested with a commercial harvester 1 week after treatment (WAT) in each experiment, and an additional harvest was made 4 WAT in Expt. 1. The depth of cut at 4 WAT in
Expt. 1 was $1.3 \mathrm{~cm}$ due to dry soil and the inability to cut deeper. Sod strips for tensile strength measurements were harvested $\approx 4$ and 8 WAT. The depth of cut again was 1.3 $\mathrm{cm}$ at 8 WAT in Expts. 1 and 3 due to dry soil.

Sod strips were cut into individual pieces $\left(900 \mathrm{~cm}^{2}\right)$ for. the post-transplant rooting measurements and were transplanted on 900$\mathrm{cm}^{2}$ squares of 9-gauge $(4 \mathrm{~mm})$ expanded steel mesh that had been lightly pressed into a tilled planting area. Transplanted sod was irrigated as needed to prevent the sod from drying. Measurements of post-transplant rooting were made $\approx 4$ weeks after harvest (WAH) by vertically lifting the steel squares from the soil using a technique similar to that described by Schmidt et al. (1986). Hooks were attached to the corners of the steel squares, and the amount of force required to lift the roots free from the soil was recorded with a 100-kg hand-held push/pull scale.

For sod tensile strength measurements, a $0.3 \times 0.3-\mathrm{m}$ piece of sod from each plot was secured on a sod-stretching device consisting of one unit mounted on a track that could be driven by an electric-powered gear activator away from an immobile frame. A push/pull gauge scale attached to the mobile unit was used to measure the force required to tear the sod when the mobile unit was placed in motion. The force [measured in a unit of mass $(\mathrm{kg})$ ] at the instant of sod break was recorded. Repeated measures were performed for each plot, averaged, and converted to units of $\mathrm{kg} \cdot \mathrm{m}^{-2}$.

The design of each experiment was a randomized complete block. Factors were biostimulators (BA, the two triazoles, SWE, and untreated) and chelated Fe (treated and untreated). Treatments were replicated four, three, and eight times in Expts. 1, 2, and 3, respectively. Analyses of variance were performed and treatment means for the rooting and tensile strength were separated by the protected LSD method. No Fe $\times$ biostimulator interaction was observed; therefore, only main effects of biostimulators are presented.

Following July application of Fe, BA, the two triazoles, and SWE, sod tensile strength measurements 4 and 8 WAT were low (Table 1, Expt. 1). Independent field studies at the Turfgrass Research Center had determined an average sod strength value of 22 $\mathrm{kg}$ for a 30-cm-wide harvestable sod piece (data not presented). The low tensile strength values were attributed to dry soil. BA increased sod strength at 4 WAT, while propiconazole and triadimefon increased sod strength by $\approx 30 \%$ at 8 WAT. Propiconazole, triadimefon, and SWE significantly increased root lift of Kentucky bluegrass 4 WAH (Table 1, Expt. 1). Triadimefon treatment resulted in root lift values that were about twice as high as untreated sod squares. BA did not significantly increase post-transplant root lift values (Table 1). Vertical root lifts $8 \mathrm{WAH}$ indicated propiconazole-treated sod had values that were $70 \%$ greater than untreated sod. Triadimefon-treated sod had root lift values that were $38 \%$ greater than those of untreated sod (Table 1). Mean root 
Table 1. Post-transplant root lift force and sod tensile strength of Kentucky bluegrass following foliar applications of biostimulators.

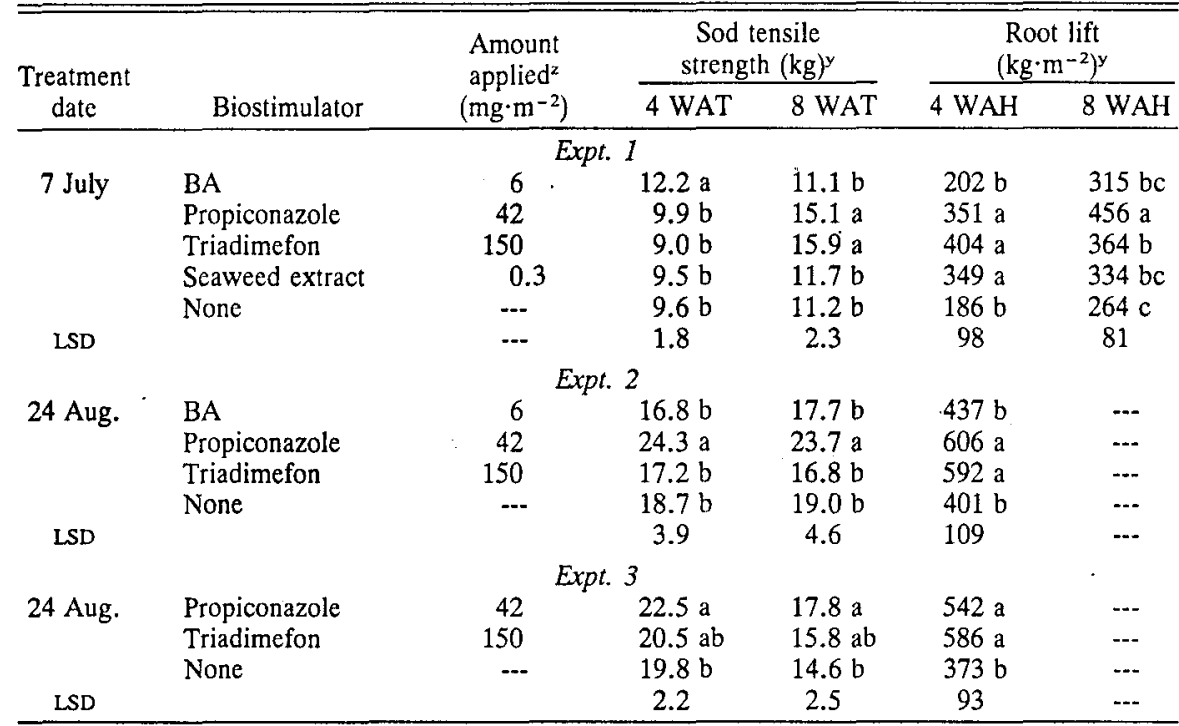

${ }^{2}$ Seaweed extract amount given in milliliters of product per square meter. All other biostimulator levels expressed in milligrams a.i. per square meter.

'WAH = weeks after harvest; WAT $=$ weeks after treatment. Mean separation in columns within each experiment by Fisher's protected LSD test, $P=0.05$.

lift values of sod treated with SWE or BA did not differ significantly from untreated sod.

Following August applications of Fe, BA, and triazoles, soil moisture conditions for the tensile strength measurements permitted sod cutting at a $2.2-\mathrm{cm}$ depth. Harvesting at this depth resulted in higher sod strengths (Table 1, Expt. 2) than those reported for the July application. Propiconazole increased tensile strength $31 \%$ at 4 WAT and $25 \%$ at 8 WAT (Table 1). Neither BA nor triadimefon increased tensile strength at 4 or 8 WAT when compared to the untreated sod. The vertical root lift $4 \mathrm{WAH}$ in Expt. 2 indicated that propiconazole and triadimefon enhanced the root lift requirement of Kentucky bluegrass $\approx 50 \%$ over the untreated sod. BA treatment did not significantly improve bluegrass rooting (Table 1, Expt. 2).

Following August applications of triazoles, sod tensile strength measurements at 4 and 8 WAT indicated propriconazole increased strength by $14 \%$ and $22 \%$, respectively, compared to the control (Table 1, Expt. 3). Tensile strength measurements for the harvest 8 WAT were lower than at 4 WAT due to sod cutting at the $1.3-\mathrm{cm}$ depth in the dry soil. At $4 \mathrm{WAH}$, triadimefon increased root lift $57 \%$ and propiconazole increased it 45\% (Table 1, Expt. 3).

Treatment with the systemic triazole fungicide propiconazole resulted in average increases in post-transplant rooting and sod tensile strength of $64 \%$ and $23 \%$, respectively, for Kentucky bluegrass across all experiments. Triadimefon increased posttransplant rooting in each experiment, but increased sod strength only at 8 WAT in Expt. 1. The results obtained do not eliminate the possibility that a fungicidal effect was present. However, the absence of obvious root and shoot pathogens indicates that these triazoles apparently can stimulate rooting and increase tensile strength of bluegrass sod by means of a nontarget, biostimulator activity.

The growth regulator-like responses of plants to triadimefon and propiconazole are proposed to be cytokinin-like. Endogenous cytokinins influence cell division and elongation, lateral bud initiation and development, and plant senescence (Wareing and Phillips, 1986). Fletcher and Arnold (1986) suggested that the growthpromoting activity of triadimefon is a result of a direct stimulation in root growth and a possible increase in endogenous cytokinin synthesis and translocation within the plant. Other growth responses exhibited by triazole-treated plants are delayed plant senescence and increased or maintained photosynthetic rates (Ballard et al., 1984; Davies et al., 1984; Goatley and Schmidt, 1990a). The observed increase in sod strength following triazole treatment indicates a stimulation in rhizome and tiller initiation and development, as previously reported for seedling Kentucky bluegrass (Goatley and Schmidt, 1990b). However, the nature of the plant response to the biostimulator activity of the triazoles apparently is concentration-dependent. Kane and Smiley (1983) reported that triazoles at 300 to $600 \mathrm{mg}$ a.i./m $\mathrm{m}^{2}$ suppressed Kentucky bluegrass root and shoot growth. Wulster et al. (1987) reported an increase in lily (Lilium longiflorum Thunb.) height when triadimefon was applied as a bulb soak at a concentration of $100 \mathrm{mg} \cdot$ liter $^{-1}$ or when propiconazole was applied as a soil drench at $20 \mathrm{mg} \cdot$ liter- ${ }^{1}$ However, applications of the triazoles as a bulb soak at $500 \mathrm{mg} \cdot 1$ iter $^{-1}$ significantly reduced lily height. The levels of triazoles used on Kentucky bluegrass in these experiments, recommended field levels as fungicide applications, provided positive growth responses.

BA, the synthetic cytokinin, significantly enhanced sod strength 4 WAT in Expt. 1 but showed very little biostimulator activity otherwise. The lack of biostimulator activity observed in this study supports previous research that determined BA was much more effective as an antisenescent agent than as a biostimulator (Goatley and Schmidt, 1990a; Tao et al., 1983). The lack of positive response in rooting was anticipated since cytokinins can inhibit lateral root primordia initiation and development (Wareing and Phillips, 1986).

\section{Literature Cited}

Ballard, J., P.S. Kettlewell, W.P. Davies, and T.J. Hocking. 1984. Evaluation of late-season fungicides for effects on leaf senescence in winter wheat. Ann. Applied Biol. (Suppl.) 104:4243.

Chernyad'ev, 1.1., A. Friedrich, A. Volfova, and A. Brezinova. 1986. Photosynthesis in sugar beet leaves under the influence of cytokinins and triazine herbicides. Photosynthetic 20:196 203.

Davies, W. P., P.S. Kettlewell H.J. Green, T.J. Hocking, and M.M. Jarai. 1984. Senescence and net photosynthesis of the flag leaf and grain growth of wheat in response to fungicide. Ann. Applied Biol. 105:303-312.

Featonby-Smith, B.B. and J. Van Staden. 1983. The effect of seaweed concentrate and a fertilizer on the growth of Beta vulgaris. Z. Pflanzenphysiol. 112:155-162.

Finnie, J.F, and J. Van Staden. 1985. Effect of seaweed concentrate and applied hormones on in vivo cultured tomato roots. J. Plant Physiol. 120:215-222.

Fletcher, R.A. and V. Arnold. 1986. Stimulation of cytokinins and chlorophyll synthesis in cucumber cotyledons by triadimefon. Physiol. Plant. 66:197-201.

Gautam, S. R., P.N. Thapliyal, and R.K. Tripathi. 1984. Effect of fungicides on physiology of plants. VIII. Effect of triadimefon on physiology of soybean plants. Indian J. Phytopath 37:600-604.

Goatley, J. M., Jr., and R.E. Schmidt. 1990a. Antisenescence activity of chemicals applied to Kentucky bluegrass. J. Amer. Soc. Hort. Sci. 115:654-656.

Goatley, J. M., Jr., and R.E. Schmidt. 1990b. Seedling Kentucky bluegrass growth responses to chelated iron and biostimulator materials. Agron. J. 82:901-905.

Kane, R.T. and R.W. Smiley. 1983. Plant growthregulating effects of systemic fungicides applied to Kentucky bluegrass. Agron. J. 75:469473.

Nelson, W.R. and J. Van Staden. 1984. The effect of seaweed concentrate on growth of nutrient-stressed greenhouse cucumbers. HortScience 19:81-82.

Schmidt, R. E., R.H. White, and S.W. Bingham. 1986. Technique to measure rooting of sods grown in small containers. Agron. J. 78:212216

Tao, G. Q., D.S. Letham, L.M.S. Palni, and R.E. Summons. 1983. Cytokinin biochemistry in relation to leaf senescence. I. The metabolism of 6-benzylaminopurine and zeatin in oat leaf segments. J. Plant Growth Regulat. 1:89-102

Wareing, P.F. and D.J. Phillips. 1986. Growth and differentiation in plants. 3rd ed. Pergamon Press, Elmsford, N.Y.

White, R.H. and R.E. Schmidt. 1988. Carbon dioxide exchange of 'Tifgreen' bermudagrass exposed to chilling temperatures as influenced by iron and BA. J. Amer. Soc. Hort. Sci. 113:423-427.

Wulster, G, J., T.J. Gianfagna, and B.B. Clarke. 1987. Comparative effects of arrcymidol, propiconazole, triadimefon, and Mobay RSW0411 on lily height. HortScience 22:601-602. 